\title{
GROWTH OF CALVES
}

\author{
J. J. HoOPER \\ University of Kentucky
}

$\mathbf{H}^{\circ}$ OW much will a Jersey calf grow in length of leg, and in depth of body as it passes from calf-hood to maturity? To secure definite information regarding the growth of calves, I measured six Jersey heifers when they were six months old and again when they had matured into four and a half year old cows. The six heifers varied from two months to seven months of age when I first measured them, but averaged six months old. The last measurement was taken when they were four and one-half years old.

I find that they average 32.8 inches high as calves, and 47.9 inches high as mature cows. They gained 15.1 inches in height. I find that 11.1 inches of the gain in height came from a deepening of body or chest, and 4.0 inches from a lengthening of the legs. From an inspection of the table it will be observed that the calves grew in length of front legs as much as two to five and one-half inches, but it will be observed that their growth in height came principally from deepening of the body.

Also I would call attention to the fact that the heifers were wider through the thurls at five months of age than through the hips, but after they had become mature cows they were wider through (or across) their hips, than across their thurls.

After the calves had been measured notes were made as to what kind of mature cows they would grow into. In checking over the notes after the heifers had matured into four year old cows, these prophecies were found remarkably correct in most instances regarding both the form of udder and of body conformation. But in one instance a nice heifer began to sway in her back at eighteen months of age, and became very swayed as a two-year old. We find that the udder and teat formation is fairly evident at five months of age.

The measurements of cows and calves are as follows:-

\begin{tabular}{|c|c|c|c|c|}
\hline Average of 6 Jerseys & $\mid \begin{array}{c}\text { Heifers } 5 \text { months } \\
\text { old, May } 1917\end{array}$ & $\begin{array}{l}\text { Cows } 41 / 2 \text { years } \\
\text { old, May } 1921\end{array}$ & Increase inches & Increase per cent \\
\hline $\begin{array}{l}\text { Ht. over withers . . . } \\
\text { Ht. to chest. . . . . . } \\
\text { Depth of chest. . . . } \\
\text { Width of chest . . . } \\
\text { Width of hips . . . . } \\
\text { Width of thurls . . . } \\
\text { Width of barrel . . . }\end{array}$ & $\begin{array}{r}32.8 \\
17.8 \\
14.9 \\
7.8 \\
8.3 \\
8.8 \\
10.9\end{array}$ & $\begin{array}{l}47.9 \\
21.8 \\
26.0 \\
14.1 \\
18.8 \\
16.3 \\
26.3\end{array}$ & $\begin{array}{r}15.1 \\
4.0 \\
11.1 \\
6.3 \\
10.5 \\
7.5 \\
15.4\end{array}$ & $\begin{array}{r}46 \\
22 \\
80 \\
81 \\
120 \\
85 \\
140\end{array}$ \\
\hline
\end{tabular}

\section{An Old Problem Restated}

The Relation Between Religion and Science: A Biological ApPROACH, by Angus Stewart Woodburne. The University of Chicago Press, 1920, pp. 103.

Speaking more precisely, Mr. Woodburne might have called his approach psychological rather than biological. He holds that science and religion have of ten been thought to be antagonistic, because the latter claimed a supernatu- ral origin; but that as a fact both of these "attitudes" are purely human in genesis, having their foundation alike in the human instincts. Science he considers to be an explanatory attitude, while religion is an evaluatory attitude. On this basis, he thinks there can be no conflict of interests, but rather there must be a co-operation of the two types of attitude, to the end that human life may be made fuller, richer, and more satisfying.-P. P. 